Genij Ortopedii. 2021. Vol. 27, no. 5. P. 587-591.

Original article

https://doi.org/10.18019/1028-4427-2021-27-5-587-591

\title{
Two-stage treatment of hip periprosthetic joint infection complicated with retroperitoneal urinary bladder defect
}

\author{
S.T. Ivanian ${ }^{1}$, S.V. Basov ${ }^{1}$, N.O. Gritsuk ${ }^{1}$, V.A. Pronin ${ }^{1}$, S.N. Tikhonenko ${ }^{2}$
}

${ }^{1}$ Rostov Regional Clinical Hospital No. 2, Rostov-on-Don, Russian Federation

${ }^{2}$ Rostov City Emergency Hospital, Rostov-on-Don, Russian Federation

Corresponding author: Sergei T. Ivanian, gavat@bk.ru

Abstract
Purpose To demonstrate the need for a multidisciplinary approach to the treatment of patients with deep periprosthetic joint infection
(PJI) and emphasize the importance of preoperative preparation and well-coordinated work of related specialists using a specific
clinical instance. Case report Reported is a successful experience of two-stage treatment of the patient with hip PJI complicated
with urinary bladder defect. A 40 -year old male patient diagnosed with left-sided deep hip PJI Tsukayama type 3 was treated at
department of infection surgery, Rostov Regional Clinical Hospital No. 2 in January 2019. Total hip arthroplasty performed in 2008
was complicated by migration of acetabulum component. A retroperitoneal bladder defect (pressure ulcer) was detected during the
first stage of resection arthroplasty and placement of an antibacterial spacer. Urological procedure was performed in a delayed manner
due to technical difficulties of implant removal, prolonged and traumatic procedure, and high blood loss. With the patient's condition
stabilized cystoscopy and bilateral ultrasound guided percutaneous nephroureterostomy were performed. Prolonged antibacterial
aetiotropic treatment was administered. The second stage of surgical treatment included revision hip arthroplasty using a tailored
acetabular component and a standard revision femoral component performed at 6 months of debridement. Results Short- and long-
term results were good with sustained remission achieved. Patient could walk unassisted using a cane and had a satisfactory ROM in
the left hip with HHS scored 76.255. Conclusion Multiple disciplinary teamwork is appropriate for treatment of deep PJI with much
coherence, coordinated efforts and expertise from diverse professionals.
Keywords: total hip arthroplasty, periprosthetic joint infection, urinary bladder defect, two stage revision arthroplasty, 3D technologies

Keywords: total hip arthroplasty, periprosthetic joint infection, urinary bladder defect, two stage revision arthroplasty, 3D technologies with retroperitoneal urinary bladder defect (case report)). Genij Ortopedii, 2021, vol. 27, no 5, pp. 587-591. https://doi.org/10.18019/1028-44272021-27-5-587-591

\section{INTRODUCTION}

The amount of primary hip replacement procedures performed increases exponentially [1]. Similarly, the number of complications and associated revision interventions increases. Periprosthetic joint infection (PJI) is the third most common cause of revision arthroplasty or the second (27.6\%) reported [2]. The risk of infection is 4 to $10 \%$ with revision interventions, and the complication rate for PJI ranges between $27 \%$ and $32.3 \%$ with revision interventions [3-6]. High treatment costs are incurred with extensive bone defects, in particular [7]. The two-stage method is the most popular treatment option for patients with PJI and successful outcomes ranging from 60 to $95 \%[3,8,9]$.

Purpose To demonstrate the need for a multidisciplinary approach to the treatment of patients with deep PJI and emphasize the importance of preoperative preparation and well-coordinated work of related specialists using a specific clinical instance.

\section{Case report}

A 40-year-old male patient was admitted to the infection surgical department of the Regional Clinical Hospital No. 2 in January 2019 and was diagnosed with deep periprosthetic hip joint infection on the left Tsukayma type 3. He had undergone total hip replacement in 2008 with acetabular component migrated later. His history included a closed fracture of the neck of the left femur from an injury sustained in 2008 that healed with a deformity, and the patient underwent total hip replacement (THR) on the left after consolidation. He sustained another trauma in 2016 and developed shortening of the left lower limb. The patient reported sinus presenting with purulent discharge at the site of the postoperative scar of the left hip in 2017 and was treated as an outpatient. He sought advice from the infection surgical service of the Regional Clinical Hospital No. 2 in December 2018 and was diagnosed with PJI and migration of implant components. The patient was examined at an outpatient clinic and then admitted to the hospital for surgical treatment.

Clinical examination revealed that the patient could ambulate using additional support, with a limited weightbearing on the left lower limb and relative shortening of $2.5 \mathrm{~cm}$. There was a postoperative scar on the lateral aspect of the left hip with signs of inflammation and a sinus with purulent-serous discharge in the mid of the scar. Probing showed the presence of a leakage in the proximal-to-medial direction. He had reduced range of motion and painful movements in the left hip. The hip was painful at palpation with slight fluctuation. No neurovascular disorder was revealed in the distal parts of the left lower limb at the time of examination. The hip joint function scored 29.825 preoperatively with the Harris Hip Score (HHS). A radiograph and fistulogram of the left hip dtd December 2018 (Fig. 1) demonstrated total hip replacement, migration of the acetabular component into the pelvis; the contrast agent injected into the sinus seen in the hip cavity enwraping the head and neck of the implant. 


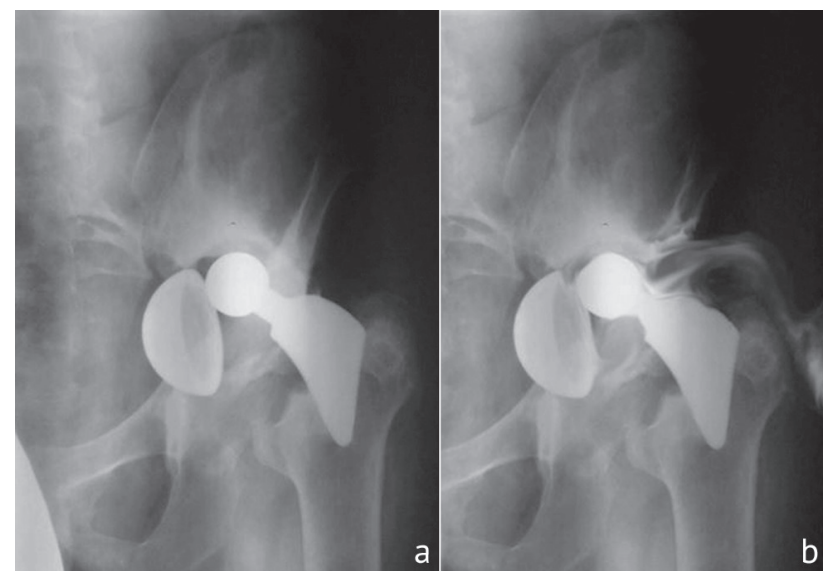

Fig. 1 A 40-year-old patient U. diagnosed with PJI of the left hip joint, migration of the acetabular component seen on the radiograph of the left hip (a) and fistulogram of the left hip joint (b)

Specialty consultant expertise including urologist's was delivered to the patient at an outpatient clinic prior to admission. Surgical procedure performed on 16.01.2019 included revision, removal of the total implant components of the left hip, sequestrnecrectomy. Pulse lavage system and antibiotic-loaded articulating cement spacer were used.

After about 20 minutes into the surgery, urine in the collection bag was noted to be stained with brilliant green that was injected into the sinus on the lateral aspect of the left hip. A urologist was asked into the operation theater and detected a retroperitoneal defect of the bladder/bedsore. A urological surgical procedure was suggested after debridement. The operation continued and the stable stem of the proximal implant fixation was removed with technical difficulties (Fig. 2). The acetabular component could not be removed using the anterior lateral approach, and retroperitoneal approach to the acetabulum was produced. The cup of the implant was removed with technical difficulties, after osteotomy of the pelvic structures making up the columns of the acetabulum. Antibiotic-loaded articulating cement spacer (40 g of bone cement impregnated with $1 \mathrm{~g}$ of gentamicin and $4 \mathrm{~g}$ of vancomycin) was placed with a pulsejet engine applied after thorough debridement, osteonecrectomy of the trochanteric portion of the femur with signs of osteomyelitis, and lavage of wounds performed (Fig. 3). Active low vacuum wound drainage system was placed and a layered suture applied to the wound. The urological surgery was delayed due to a prolonged 5-hour traumatic orthopaedic procedure and high blood loss $(800 \mathrm{~mL})$. The patient was delivered to the intensive care unit.

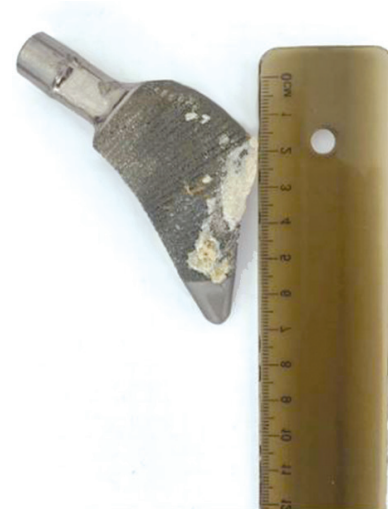

Fig. 2 The femoral component of the cementless implant fixation removed

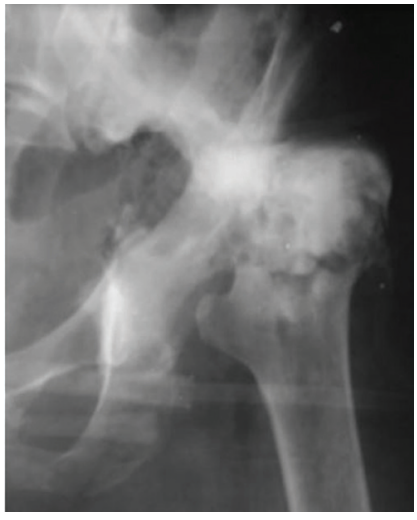

Fig. 3 Radiograph of the left hip joint after the first surgery with antibioticloaded articulating cement spacer placed
Cystoscopy and ultrasound guided bilateral percutaneous nephro-ureterostomy were performed on 17.01.2019 in patient's condition stabilized (Fig. 4). Foley urinary catheter was recommended to be used for 3 weeks and nephrouterostomy, for 4 weeks.

MRSA was isolated from tissue intraoperative biopsies. Systemic antibacterial therapy (ABT) included a course of vancomycin $1 \mathrm{~g}$ intravenously (intravenous drip) 2 times per day ( $t / d$ ) for 10 days, ciprofloxacin $600 \mathrm{mg}$ i/v dr. $2 \mathrm{t} / \mathrm{d}$ for 10 days, with the transition to oral suppressive ABT with levofloxacin $500 \mathrm{mg} 2 \mathrm{t} / \mathrm{d}$, rifampicin $300 \mathrm{mg} 2 \mathrm{t} / \mathrm{d}$ for 6 weeks. Wound healed with primary intension and the patient was discharged from the hospital after 17 days. The left hip was immobilized with commercially available spica cast.
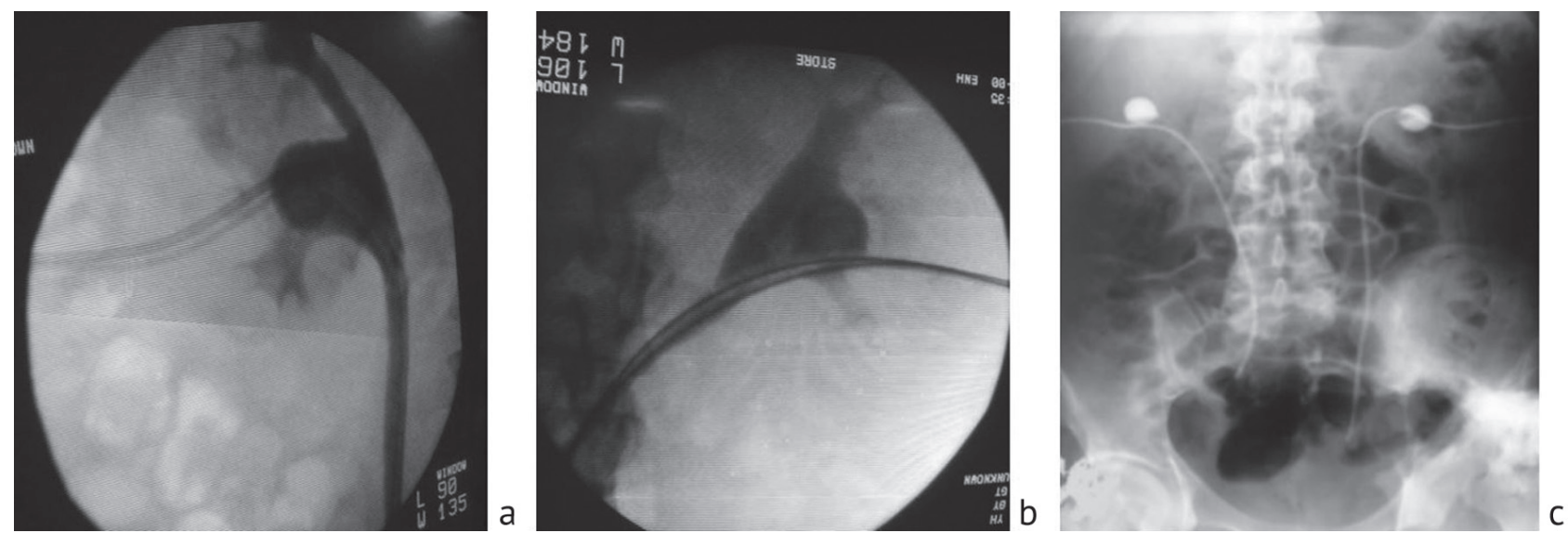

Fig. 4 Urogram: intraoperative radiological control of nephroureterostomy of the left and right kidney with image intensifier (a, b); control urogram produced on the next day after surgery 
Definitive diagnoses included (a) the primary diagnosis of a deep PJI of the left hip joint Tsukayma type 3, total hip replacement in 2008, migration of the acetabular component into the pelvis, chronic secondary osteomyelitis $2 \mathrm{~B}(\mathrm{l}, \mathrm{s})$ of the proximal epiphysis of the left femur, defect of the acetabulum Paprosky type 3A on the left, defect of the proximal femur Mallory type II on the left; (b) retroperitoneal defect of the bladder wall as a complication of the primary condition; (c) secondary diagnosis of chronic viral hepatitis $\mathrm{C}$, chronic sinusitis at stage of remission. The urinary catheter was removed on 11.02.2019 and nephrostomas were removed on 18.02.2019. The nephrostomes healed by primary intension. Triple needle aspiration cultures were taken from the left hip two weeks after ABT with no pathogen detected. Blood parameters showed counts within normal limits (L, $6.7 \times 109 / \mathrm{L}$; ESR, $29 \mathrm{~mm} / \mathrm{h}$; CRP, $3.2 \mathrm{mg} / \mathrm{L}$ ).

Infection was arrested and the patient scheduled for the second stage of revision hip replacement using a tailored acetabular component fabricated with additive manufacturing technology. For this, the patient underwent $0.5 \mathrm{~mm}$-slice spiral computed tomography (CT) of the pelvis and 3D reconstruction (Fig. 5). The CT data were e-mailed to $3 \mathrm{D}$ printing engineers to model the acetabular component to allow replacement of acetabular defects, restoration of the center of rotation of the femoral head and fixation to three pelvic bones using screws (Fig. 6).
The second stage of revision arthroplasty using a tailored individual acetabular component and a standard revision stem was performed on 21.06.2019. (Fig. 7). Antibacterial therapy was used postoperatively to include vancomycin $1 \mathrm{~g}$ i/v drip $2 \mathrm{t} / \mathrm{d}$ for 7 days. The patient was encouraged to ambulate after 3 postoperative days. The patient was recommended to use additional means of support and limited weightbearing on the left lower limb up to $20 \%$ of body weight for 4 weeks and then gradually progress to full weight-bearing. The postoperative wound healed by primary intension. The patient was discharged from the hospital after 14 days.

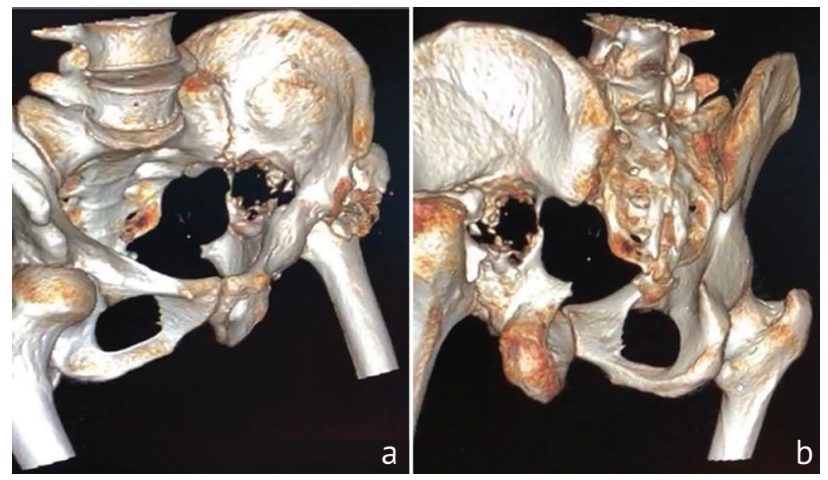

Fig. 5 Spiral CT scan of the pelvic bones of patient U. performed after the first stage of surgical treatment and a course of antibacterial therapy. 3D reconstruction showing oblique (anterolateral) view of the acetabulum on the left (a); oblique (posterolateral) view (b)

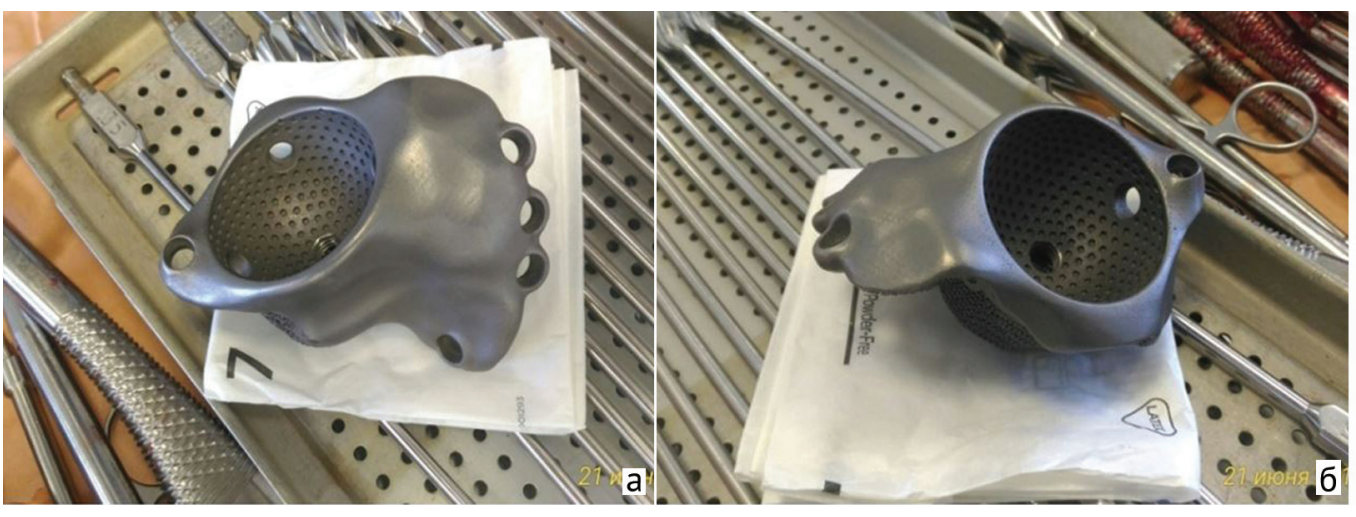

Fig. 6 Acetabular component of the total implant for the left hip manufactured using 3D printing: different views of the acetabular component $(\mathrm{a}, \mathrm{b})$

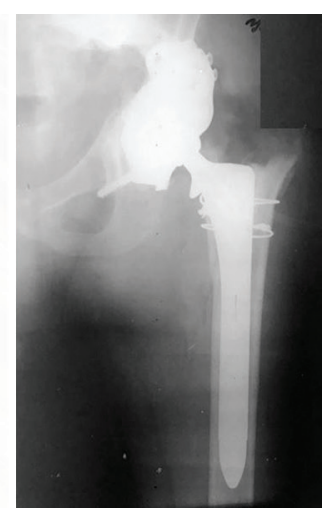

Fig. 7 Anteroposterior radiographic view of the left hip joint after the second stage of revision arthroplasty

\section{RESULTS}

Short- and long-term follow-ups were rated as good with stable remission of the infectioous process achieved. The patient could ambulate unassisted using a cane and had a satisfactory range of movements in the left hip joint with $90^{\circ}$ flexion, $180^{\circ}$ extension and $25^{\circ}$ abduction. The hip joint function scored 76.255 on the HHS scale at one year following revision arthroplasty.

\section{DISCUSSION}

Two-stage replacement of joint arthroplasty for PJI is considered the best option [6]. However, there are a limited number of publications in the available literature focusing on a comprehensive solution to PJI of the hip joint complicated by an injury to the pelvic organs.
Yacovelli S., Parvizi J. [10] suggested an interdisciplinary approach as the ideal treatment model for PPI in the article "Who should manage periprosthetic joint infection? The Case for a Multidisciplinary Approach". They reported the importance of treating 
PJI in hospitals with the possibility of multidisciplinary care under the lead of a subspecialized orthopedic surgeon with experience in treating PJI. The article emphasizes the need to include radiologists, clinical pharmacologists, microbiologists, endocrinologists, hematologists, nephrologists, anesthesiologists, rehabilitologists, physiotherapists in the team. Everyone's expertise is important from diagnosis of PJI to the complete rehabilitation of the patient.

Discussing the clinical case, it is necessary to note the shortcomings of the diagnostic measures carried out and the questions that arose during treatment.

Computed tomography (CT) had not been performed for the patient. CT angiography can provide additional diagnostic information and can be extremely valuable in preoperative planning in patients with defects of the acetabulum roof and the acetabular component of the implant migrated into the pelvic cavity. The results of the investigations can help to avoid serious complications during surgical intervention [11]. Would a CT scan have revealed a retroperitoneal bladder defect? Although urologists, co-authors of the article, and literature sources report a high probability of visualization of the condition on a plain CT scan, retrograde cystography is a valuable method for diagnosing a bladder injury allowing identification of the type of injury (intra- or retroperitoneal) and the approximate localization through location of urinary extravasation [12]. How would have the treatment strategy changed if a bladder defect had been detected preoperatively? There is no single answer to the question. No information was found in the literary sources. A urological surgical procedure would have been likely to be performed at the first stage to be followed by debridement of the PJI. The available scientific articles report cases of intraoperative injury to the bladder. Konopitski A et al. [13] and Grauer $\mathrm{JN}$ et al. [14] reported a case of interoperative bladder perforation treated with bladder decompression using a Foley catheter, antibiotic administration, hemodynamic monitoring, and urology consult with close followup. The case reinforced the importance of urologic preoperative evaluation for anatomic variations of the bladder. Extensive acetabular defects are likely to make the second stage of surgical treatment more difficult and would necessitate a thorough preoperative analysis and planning, specific surgical technique and implant selection [15]. 3D technologies can provide solutions for the challenging cases.

The clinical case presented demonstrates a possible mechanism for the treatment of PJI complicated by retroperitoneal bladder defect. Reported are stages of treatment of a patient in a multidisciplinary hospital, shortcomings of management discussed and ways to solve them offered.

\section{CONCLUSION}

Literature review and the outcome of the clinical observation suggest that a thorough preoperative analysis, multidisciplinary approach are essential for successful surgical treatment of deep PJI to be performed by a skilled, specially trained orthopaedic surgeon in a hospital wth a collaborative effort amongst a variety of medical professionals. Multiple disciplinary teamwork is appropriate for treatment of deep PJI with much coherence, coordinated efforts and expertise from diverse professionals.

\section{REFERENCES}

1. Andreeva T.M., Ogryzko E.V., Popova M.M., comp. Eskin N.A., editor. Travmatizm, ortopedicheskaia zabolevaemost, sostoianie travmatologo-ortopedicheskoi pomoshchi naseleniiu Rossii v 2018 godu: sbornik [Traumatism, orthopedic morbidity, the state of traumatological and orthopedic care for the population of Russia in 2018: collection of works]. M., TsITO im. N.N. Priorova, 2019, 166 p. (in Russian)

2. Shubniakov I.I., Tikhilov R.M., Denisov A.O., Akhmedilov M.A., Chernyi A.Zh., Totoev Z.A., Dzhavadov A.A., Karpukhin A.S., Muraveva Iu.V. Chto izmenilos v strukture revizionnogo endoprotezirovaniia tazobedrennogo sustava v poslednie gody? [What has changed in the structure of revision hip arthroplasty in recent years?]. Travmatologiia i Ortopediia Rossii, 2019, vol. 25, no. 4, pp. 9-27. (in Russian) DOI: 10.21823/2311-2905-2019-25-4-9-27.

3. Liu B., Tikhilov R.M., Shubniakov I.I., Bozhkova S.A., Artiukh V.A., Denisov A.O. Analiz effektivnosti saniruiushchikh operatsii pri paraendoproteznoi infektsii [Analysis of the effectiveness of sanitizing surgeries for paraendoprosthetic infection]. Travmatologiia i Ortopediia Rossii, 2014, no. 2, pp. 22-29. (in Russian). DOI: 10.21823/2311-2905-2014-0-2-22-29.

4. Prokhorenko V.M., Pavlov V.V. Infektsionnye oslozhneniia pri endoprotezirovanii tazobedrennogo sustava [Infectious complications in the hip arthoplasty]. Novosibirsk, Nauka, 2010, 179 p. (in Russian)

5. Everts R.J., Chambers S.T., Murdoch D.R., Rothwell A.G., McKie J. Successful antimicrobial therapy and implant retention for streptococcal infection of prosthetic joints. ANZ. J. Surg., 2004, vol. 74, no. 4, pp. 210-214. DOI: 10.1111/j.1445-2197.2004.02942.x.

6. Uchiyama K., Takahira N., Fukushima K., Moriya M., Yamamoto T., Minegishi Y., Sakai R., Itoman M., Takaso M. Two-stage revision total hip arthroplasty for periprosthetic infections using antibiotic-impregnated cement spacers of various types and materials. Scientific World Journal, 2013, pp. 147248. DOI: 10.1155/2013/147248.

7. Murylev V.Iu., Kukovenko G.A., Elizarov P.M., Ivanenko L.R., Sorokina G.L., Rukin Ia.A., Alekseev S.S., Germanov V.G. Algoritm pervogo etapa lecheniia pozdnei glubokoi periproteznoi infektsii tazobedrennogo sustava [Algorithm of the first stage of treating late deep periprosthetic infection of the hip]. Travmatologiia i Ortopediia Rossii, 2018, vol. 24, no. 4, pp. 95-104. (in Russian). DOI: 10.21823/2311-2905-2018-24-4-95-104.

8. Kovalenko A.N., Shubniakov I.I., Bilyk S.S., Tikhilov R.M. Sovremennye tekhnologii lecheniia tiazhelykh kostnykh defektov v oblasti vertluzhnoi vpadiny: kakie problemy reshaiut individualnye implantaty? [Modern technologies for the treatment of severe bone defects in the acetabulum: what problems can individual implants solve?]. Politravma, 2017, no. 1, pp. 72-81. (in Russian). 
9. Jaeblon T. Polymethylmethacrylate: properties and contemporary uses in orthopaedics. J. Am. Acad. Orthop. Surg., 2010, vol. 18, no. 5, pp. 297-305. DOI: 10.5435/00124635-201005000-00006.

10. Yacovelli S., Parvizi J. Kto dolzhen lechit periproteznuiu infektsiiu: neobkhodimost multidistsiplinarnogo podkhoda [Who should manage periprosthetic joint infection?: the case for a multidisciplinary approach]. Travmatologiia i Ortopediia Rossii, 2019, vol. 25, no. 4, pp. 28-32. (in Russian). DOI: 10.21823/2311-2905-2019-25-4-28-32.

11.Artiukh V.A., Bozhkova S.A., Kochish A.Iu., Shneider O.V., Razorenov V.L., Bazarov I.S. Diagnostika i lechenie periproteznoi infektsii tazobedrennogo sustava. Rukovodstvo po khirurgii tazobedrennogo sustava: $v 2 t$. [Diagnosis and Treatment of Periprosthetic Hip Infection. Guide to Hip Surgery: in 2 vol.]. SPb., RNIITO im. R.R. Vredena, 2015, vol. 2, pp. 208-257. (in Russian)

12.Davidov M.I., Gerner A.O., Nikonov O.E. Algoritm diagnostiki i lecheniia vnutribriushinnogo razryva mochevogo puzyria [Algorithm for the diagnosis and treatment of intraperitoneal bladder rupture]. Eksperimentalnaia $i$ Klinicheskaia Urologiia, 2016, no. 4, pp. 116-121. (in Russian)

13.Konopitski A., Boniello A., Wang P., Shah M., Old A., Gingrich K. Intraoperative bladder perforation during primary total hip arthroplasty. Arthroplast. Today, 2017, vol. 4, no. 1, pp. 40-43. DOI: 10.1016/j.artd.2017.03.008.

14.Grauer J.N., Halim A., Keggi K.J. Bladder tear during revision total hip arthroplasty. Am. J. Orthop. (Belle. Mead. N.J.), 2014 , vol. 43, no. 8, pp. E185-E188.

15.Tikhilov R.M., Shubniakov I.I., Kovalenko A.N., Denisov A.O., Bilyk S.S. Pokazaniia k revizionnomu endoprotezirovaniiu tazobedrennogo sustava, planirovanie i tekhnika revizionnoi operatsii. Rukovodstvo po khirurgii tazobedrennogo sustava: $v 2$ t. [Indications for revision hip arthroplasty, planning and technique of revision surgery. Guide to Hip Surgery: in 2 vol.]. SPb., RNIITO im. R.R. Vredena, 2015, vol. 2, pp. 258-355. (in Russian)

The article was submitted 19.01.2021; approved after reviewing 01.03.2021; accepted for publication 23.08.2021.

\section{Information about the authors:}

1. Sergei T. Ivanian - M.D., gavat@bk.ru, https://orcid.org/0000-0003-1700-1416;

2. Stanislav V. Basov - Candidate of Medical Sciences;

3. Nikolai O. Gritsuk - M.D.;

4. Vladimir A. Pronin - M.D.;

5. Sergei N. Tikhonenko - M.D.

Publication ethics The patient gave informed consent for publication of the findings without identification.

Conflict of interests The authors declare that there is no conflict of interest. 